Review Essay

\title{
An all-too-human future? Revolution, utopia and the many lives of humanity
}

\author{
Transhumanism: Evolutionary Futurism and the Human \\ Technologies of Utopia \\ Andrew Pilsch \\ University of Minnesota Press, Minneapolis, 2017, 257pp., \\ ISBN: 978-1-5179-0102-8
}

The Spirit of Revolution: Beyond the Dead Ends of Man

Drucilla Cornell and Stephen D. Seely

Polity Press, Cambridge, 2016, viii+195pp.,

ISBN: 978- 0-7456-9075-9

\section{For Humanism: Explorations in Theory and Politics}

David Alderson and Robert Spencer (Eds.)

Pluto Press, London, 2017, viii+240pp.,

ISBN: 978-0-7453-3614-5

Contemporary Political Theory (2020) 19, S91-S99. https://doi.org/10.1057/s41296018-00302-y; published online 1 January 2019

At a time when various forms of posthumanist, post-anthropocentric and morethan-human approaches and sensitivities have become pervasive in debates in cultural theory and social sciences, the publication of three books taking on the role of the human and its future for contemporary political theorising may appear bold, if not against the contemporary grain. The reasons for bringing together Pilsch's Transhumanism: Evolutionary Futurism and the Human Technologies of Utopia; Cornell and Seely's The Spirit of Revolution: Beyond the Dead Ends of Man and Alderson and Spencer's For Humanism: Explorations in Theory and Politics may not be straightforward. Published in the last two years, the central concern of the three works is an engagement with the idea of the human, with how this idea(l) has shaped philosophical pasts and cultural practices and, more importantly, whether (and how) it is possible to move beyond the human in orienting and reimaging the possibility of a shared political future.

(C) 2019 Springer Nature Limited. 1470-8914 Contemporary Political Theory Vol. 19, S2, S91-S99 
At a quick glance, the books may appear antithetical to each other. Pilsch's declared aim to reject 'the state-of-the-art theories about the end of the human and the limits of reason' (p. 4) at the very opening of his work seems to take issue precisely with Cornell and Seely's stepping stone: the assertion of the dead ends of Man and the search for an alternative route towards an emancipatory project that redraws the 'geographies of reason' in favour of an opening towards spirituality. For them, Man has proven guilty of fostering narratives of phallocentrism and heteronormativity, which feminisms and queer theory have so effectively unveiled (p. 2). In their pieces in the collection, Alderson (pp. 163-209) and Spencer (pp. 120-162) position themselves in yet another side of the battlefield and try to demonstrate how, in fact, a humanist trail can be detected even in the least expected territories of queer and postcolonial studies.

When it comes to define the critical object that all authors engage, however, a certain agreement begins to emerge: for centuries, dominant understandings of the human have been shaped after '(those) ideals of human perfectibility, rationality, and agency inherited from the Renaissance humanism and the Enlightenment' (Wolfe, 2009, p. xiii). Thus, indulging the temptation of declaring the end of humanity - an imaginary that the culmination of discourses around the Anthropocene, the geological era marked by the irreversible footprint that humans are leaving on the planet, has made the most vivid - means giving in to the apocalyptic scenario of not only passively waiting for humanity's death, but even to celebrate it as the compensation for the centuries of destruction of others and the earth that current posthumanist approaches have exposed. Yet, as Pilsch asks, voicing one of the claims of the transhumanist agenda: 'Why would you choose to die?' (p. 5). Cornell and Seely seem to share the same objection when, engaging with Claire Colebrook's (2014) denunciation of the contradictions inherent to today's posthumanism, they notice that 'we have had quite enough of the contingent, fragile, insecure, and ephemeral lives' (p. 4) that the current ecological crisis seems to demand from the human predicament. This much heated and still open debate provides the overarching question with which the three books engage: how to move beyond the human without entirely dismissing the legacy of emancipation, freedom and opening of new futures that humanism has taken upon itself?

The common polemical object is made further clear in the introduction of For Humanism, when Brennan states that the book offers 'a vital prolegomenon ... laying out a field of thought and action that pre-empts the appeal of posthumanism by offering us another, and earlier, story of language and sensibility' (p. 15). The collection takes issue primarily with anti-humanist discourses, which have contributed to forge an acute critique of humanist values by treating them as paired up with modern liberal logics. At the same time, the book does not dismiss a direct engagement with posthumanism, which is here defined as moving in the direction of a subordination of human prerogatives to an indifferent nature .... It 
speaks in terms of anthropological mutation. Scientism, we could say, is the most pronounced form today of post-humanism' (p. 8). Posthumanism, with its tendency to downplay the human and distribute agency within a wider material cosmos of interactive processes, has been gaining momentum in political and social theorising, even though the book's characterisation of the discourse would possibly find disagreement, by linking it to names such as Gilles Deleuze, Michel Foucault, Donna Haraway and Bruno Latour, among many others.

Most importantly, however, the authors seem to agree with the argument raised elsewhere (Cornell and Seely through the thought of Colebrook) that posthumanism is appearing more and more as a reassertion of the human: 'The human, they pervasively show, is the being beyond which we cannot think - the creature who, we might say in the present context, is so utterly free as to invent the "post-human" for ethical reasons, wilfully pretending thereby to have demonstrated its lack of will' (p. 11). Therefore, if their rendering of posthumanism can be questioned, it is also difficult to resist the claim that it is a massively willed and historically determined effort to be done with will and history' (p. 12).

The benchmark of 'end of Man' and the consideration of the place and possibilities for humanity after it can thus provide the axis (logical and intellectual, more than chronological) along which the arguments of the three books can be situated and put in relation to each other. Still, the answers with which the authors address the core questions spelled out above remain different. Pilsch takes the standpoint of transhumanism as the shuttle to embark into the journey of rethinking a future beyond the human. The approach to the topic is original and one of the merits of the book is to demonstrate how the trajectory of transhumanist discourse is much diverse and plural and by no means can be reduced to the stereotypical view inspired by certain branches of science fiction (for him, often taken too seriously) or by current circles dreaming of the transformation of the human into a fully technologised machine, transpassing the new frontiers of artificial intelligence and scientism (the very transhumanist dream of downloading one's entire consciousness into the RAM of a computer by pressing one single button well captures this version; also in Hayles, 1999). The discussion that Pilsch offers is instead played on the triangulation of transhumanism with the rhetoric of evolutionary futurism and the possibility for utopia. Transhumanism, as a continuation of the human that at the same time moves the human to a new status, is discussed as the projection towards a futurity in which humans are transformed into a kind of posthumanity through the use of technologies that can extend human capacities and that encompass both the human body and the human soul as the material for reimagining these futures. What is probably the most interesting twist in this discussion from a political perspective - and in fact, what enables a connection with the other works discussed in this review - is that this future projection around the evolution of the human is tied to the reinvention of the very function of utopia. The task that an evolutionary transhumanism of the type

(c) 2019 Springer Nature Limited. 1470-8914 Contemporary Political Theory $\quad$ Vol. 19, S2, S91-S99 $\quad$ S93 
that Pilsch describes takes upon itself is the call for a post-Marxist utopian praxis for the 21 st century. The communist idea of a classless society needs to make space for an imaginary that takes the body and not the state and its welfare programmes as the site for a new utopian vision of progress.

Cornell and Seely are equally interested in interrogating the future possibilities of a revolutionary politics that stems from the failure of (and counters the social and political oppressions caused by) the philosophy of Man. Similar to the other works, this does not mean rejecting the past, but rather carrying on those elements that can enhance an alternative trajectory to think a future of emancipation for humanity. If Man is dead, this does not need to apply to the human too: its roots and values delve much further and deeper than the Western image of Man passed down through history. The elements to be maintained and brought forward are the possibility of a re-politicisation of political participation and collective revolutionary action, which draw not so much from the domain of reason and thinking but reveals itself as infused by the experience of political spirituality. Therefore, by opening up to geographies that span Caribbean, African and Islamic thought, it is possible to appreciate how spirituality has proven an invaluable resource accompanying the responses and struggles against the deep traumas caused by colonisation and capitalism, and thus closely intertwined to the opening of political possibilities.

Finally, Alderson and Spencer would probably deny the statement that an 'end' of human has ever occurred. This is because the human who provides the only, broad category situated at the core of any form of humanism is far from being identified with the tradition of the Western Man only. The strength of their contribution is to highlight that what it means to be human cannot manifest itself, if not through a variety of historical and social forms (p. vii). Humanism has been present, even if perhaps disguised, in approaches and trajectories that may appear completely antithetical to it (and that claims around anti-humanism have incapsulated at their best). Retracing the trajectory of those approaches is therefore essential for any theoretical and political attempts that aim to move any serious account of the future of humanity forward.

A further commonality among these books thus comes to surface: if the idea of Man is a shared concern for the authors engaged, it is identified more with the version that current anti- and posthumanist approaches have crafted than with the ideas of renovation, emancipation and freedom that accompany the multiple forms of humanism, and particularly the one drawn from a Marxian perspective. These authors' shared goal is not rejecting the latter version as much as 'correcting' it, in light of the new advancements offered by modern-day technology (Pilsch), or by elements (spirituality for Cornell and Seely) and discourses (from poststructuralism, to postcolonialism and queer theory for Alderson and Spencer) that have been excluded from narratives of humanism.

It is significant that, to a different extent, all the works also draw from another dimension associated with socialist humanism: the idea and function of utopia. The 
traditional meaning of the term, inherited in political literature from Thomas More, famously denotes a place that is simultaneously ideal and not existent. The application and deployment of the term in all the arguments here explored borrow from - and simultaneously amend - both meanings: the utopia for the future enabled either by a transhumanist futurity or by the rediscovery of political spirituality is not a destination, but an 'endlessly receding horizon' (Pilsch, p. 18). This means that these projects remain politically productive because they can open up new avenues for the imagination, new political possibilities for enabling and inspiring change. Therefore, they function as a method and desire - more than as any final statement of a condition to come. Pilsch suggests capturing this understanding of utopian thought as an 'extropia' (p. 18), following a trajectory drawn less from Marx than from Fredric Jameson (2005). The concern with all these projects is a re-engagement with a revolutionary politics, one that could even require the very redefinition of the idea of the 'political'. Acknowledging the 'dead ends' of Man does not amount to prefiguring another actual status that needs to be accomplished and realised (lest the potentially detrimental consequences that forms of utopia have achieved in the past) but to opening up new possibilities for brining new worlds into existence by means of revolutionary emancipatory struggle.

In the same way, thinking in terms of 'utopia', according to the contributors of For Humanism, means offering an alternative to the current climate of content with the status quo: utopia is a moving horizon to think within. In the collection, Barbara Epstein reclaims utopian thinking in the discussion of the legacy and importance of socialist humanism, one that uses utopia as a necessary intellectual framework for change, regardless of whether the imagined future for humanity can actually be accomplished: formulating a goal to aspire to is the condition for moving forward. Anderson notes that humanism (and for him particularly in the trajectory of Marxian and radical humanism of post-World War II) 'comes to the fore only at times when there is a real hope of positive revolutionary change' (p. 89), especially against the dehumanised global capitalist system. Cornell and Seely seem to share a similar perspective when adopting Immanuel Kant's invitation (p. 12) to act according to the duty of conforming to the ideal that one strives for (be it progress, perpetual peace or, in the case of the book, the end of capitalism). Aspiring to revolutionary futures is sensible not because the actors of such enterprise can have any certainty that such goal can be accomplished. Rather, it is the simple living as if the goal can be obtained that provides the first condition to approximate the desired future.

The discussion of utopia helps highlight another shared commitment by these authors: a need to look back at a form of radical humanism as the ground for thinking forward. Karl Marx could thus be seen as the common spectre lingering across the works: all of them reinterpret and refigure the aim of fostering a new project for humanity aimed at freedom and emancipation. Some of the contributors go even further, by advocating this as a step towards a reinvigoration of the

(C) 2019 Springer Nature Limited. 1470-8914 Contemporary Political Theory $\quad$ Vol. 19, S2, S91-S99 S95 
political Left. Epstein, for instance, calls for a return to the socialist humanism of the 1950 s-60s as a source for facing contemporary challenges by building upon possibilities of human collective and constitutive action. For them, the future means not hoping that the hegemonic capitalist system could simply fade away; rather, the Left should formulate a vision of the future that is more democratic and sustainable, and thus more capable to offer a feasible counter-hegemony.

Theoretically, another merit all these books display is their foregrounding of an extraordinary rich and often not sufficiently explored body of contributions, which can be brought under the umbrella term of 'humanism'. The methods used by the authors are different: while Pilsch and the authors in Alderson and Spencer's collection carry out a genealogical work and retrace forms of transhumanism and humanism, respectively, beyond the sources commonly associated with these discourses, Cornell and Seely proceed mainly through the free association and combination of thinkers across geographies and times, with the aim of recomposing, or 'creolising' the way in which the reception of certain authors has been transmitted, especially in Western scholarship. Thus, in Pilsch, we find references to most diverse and broad transhumanist literature which particularly rejects the identification of this movement with a type of techno-obsessed, sci-fi driven mode of scientism. The author engages with thinkers spanning political and cultural theory and poetry from Friedrich Nietzsche and his re-readings in modernist literature (in authors such as Loy and Ouspensky) to Francis Fukuyama's 'bioconservatism' and his simultaneous dismissal and endorsement of science fiction as a (false) proxy for transhumanism; to Isabelle Stengers and her critique to the entrepreneurial culture of speed and action that characterise the contemporary cybercultural milieu.

The essays in the collection by Alderson and Spencer revisit the legacy of antihumanist critiques and run a reading of humanism through poststructuralist, queer and feminist and postcolonial approaches. The merit of the work is precisely reminding the readers of the diverse nature of humanism and that any undifferentiated critique that takes it as a fixed label, and tars 'all humanisms with the same brush' (p. 89) is limiting and misleading at best. The aim of the book is thus to demonstrate how the many and different types of humanisms, from socialist to radical to the ones found in queer studies, have always provided a path towards revolutionary change. If liberal humanism has crystallised the 'human' in a series of abstractions which have engendered inequalities, oppressions and exclusions, a return to socialist and Marxist humanism means vindicating humanism's multiple genealogies beyond its most common identification and pairing with the capitalism of the 19th century colonial enterprise.

Finally, Cornell and Seely map out new geographies of political spiritualities that merge Western thinkers (Foucault, Jacques Lacan, Spinoza) with authors from the global South (Ali Shari'ati, Frantz Fanon and Sylvia Wynter), in an enterprise 
that both literarily and practically can generate new encounters and breach the artificial divides of the current episteme.

A renewed idea of the human is therefore the constant that brings together the three accounts. Yet it appears less as a normative standard than an aspirational idea to invite new ethical and political projects. The focal role of the idea of the human as a point around which to build and envision a new politics and a different future is what marks their difference from purely critical attempts that see resistance (to dominant narratives, to the hegemony of the liberal idea of Man and, above all, to capitalism) as the only possible political gesture. This is captured by Alderson and Spencer's open engagement with anti-humanism and forms of anti-episteme, or with Pilsch's attribution of a negative character to various posthumanist critiques. As the former notice by recalling a famous exchange in a televised interview between Noam Chomsky and Foucault in 1971, the social order cannot be criticised without a 'humane' grasp of that nature as frustrated and repressed (p. 213). In other words, a true critique cannot start from nowhere, if any challenge to the present has to consist not in a mere rhetorical exercise but aspires to take the form of a concrete programme of transformation and action. For all of them, this perhaps bold but necessary starting point is identified with a socialism that looks at community and collectivity as the space and domain for any new political enterprise.

It is at this point, however, that the limits of the different projects emerge. If their criticism against approaches that only apparently criticise the status quo - and that ultimately just reinforce the current situation and bring back the idea of Man, if perhaps through the back door - is correct, the books here analysed may be deemed to remain prey of a similar impasse: even though advocating for a clear content and agenda, the way in which these can be translated into action is less clearly spelled out. Put differently, if a recuperation of the idea of the human and the values of freedom, emancipation and liberation that pertain to humanism beyond its liberal version (too much and too often subordinated to the logics, needs and interest of capital) seem to provide the necessary starting point for a new politics of transformation, the way in which humanism may help develop this enterprise is less defined. How can the multiple forms of humanisms that the authors invite us to recuperate help re-envision a different, more just, non-capitalist future? I would argue that this impasse pertains to two dimensions in particular.

First, I want to raise a concern about the end point that some of the authors surprisingly share. In their quest for a new transformative project able to defeat capitalism and achieve freedom and human flourishing, Pilsch and Alderson and Spencer see current work in 'accelerationism' as promising for delivering a more just and free future for humanity. They both quote Srnicek and Williams' manifesto for an 'accelerationist politics' (2014) as a feasible political project for freeing individuals from the burden of work and returning them to a status of freedom. Pilsch further combines this perspective with the thesis recently emerged from Laboria Cubonik's Xenofeminist Manifesto (2018). The idea of acceleration is

(c) 2019 Springer Nature Limited. 1470-8914 Contemporary Political Theory $\quad$ Vol. 19, S2, S91-S99 $\quad$ S97 
supposed to deliver an antidote against the malaise of capitalism and raise humanity to a new status. For Pilsch in particular, this can be suitably combined with the rapid pace of technological advancements subordinated to a future that has not yet been assigned a particular over-determination and directionality. The force of accelerationist projects, according to the authors, is remaining open to forms of radical political experiments where the outcome is not determined in advance. I understand the need to call for a plan that does not risk repeating mistakes of the past. However, by advocating accelerationism as the way beyond capitalism, the authors' contribution may end up resembling the very discourses they have criticised all along, and posthumanist and affirmative perspectives in the first place. Benjamin Noys (n.d.) well captures this criticism by equating all critical approaches that advocate political projects based on the affirmation and celebration of life as yet another example of the 'poverty' of the many forms of contemporary vitalism. To use a sentence from Aldersen and Spencer against them: any visions of the future 'count for nothing without any identifiable forces that bring them to effect' (p. 221). Calling for an accelerationist movement that expands but does not fundamentally challenge the historicity, conditions of possibility and status through which capitalism works seems to fall into the unresolvable circularity ascribable to forms of affirmationist critique.

A second point, this time shared by Pilsch and Cornell and Seely, is the question around the level at which the process of transformation should be pursued. Is the individual the locus of any new emancipatory project, or is the collective dimension of a community that works together and is able to push its own future further? There is no doubt that the authors would opt for the latter. But then, the way in which this enterprise can be realised is more blurred and less defined. Both Cornell and Seely and Pilsch advocate a form of 'self-mastery' that should be pursued for humanity to transcend its own status and develop towards something different. This collective self-mastery is described by Pilsch as the "creation of processes for overcoming the limitations of all bodies and minds for universal transcendence against the ephemeral power bought by money or status' (p. 202). It is the collective self-mastery as the attempt at continuous and experimental extrapolation of what humans can do, without yet defining this capacity a priori, that can exclusively guarantee that humanity might live forever (Pilsch, p 199).

Cornell and Seely, who more explicitly call for a return to socialism, advocate a form of new collective praxis of being human beyond the brutalities of Man, and inspired by the revolutionary capacities opened up by spiritual transformation. Once again however, the way out of the current frictions, limits and inequalities that capitalism produces seems very much to bypass the conditions created by capitalism, rather than working through them. Two concerns can be highlighted at this point: first, the approaches call for a new politics of action and transformation and not one of resistance. Yet, as far as this takes place as an acceleration of the current dynamic of capitalist production and economic organisation, this outcome 
seems not too distant from affirmationist attempts common to the approaches that all the authors discussed here try so carefully to criticise and distinguish themselves from. Secondly, projects of self-mastery and transformation seem to rely on a highly reflexive attitude that pertains to the individual - rather than the collective and thus reproduce the assumptions that the authors try to take distance from.

Therefore, if the merit of the three works is to foreground that the rich and often simplified legacy of the humanist tradition does not need to be left aside and abandoned in order to imagine new collective futures, the means to materialise this aspiration remains still to be defined. While the books demonstrate that the possibility for a different political future can still be all-too-human - and indeed, this attempt should be welcomed against perspectives that seem to celebrate the limits of the possibilities open to humanity - outlining what this revolutionary human could look like still has some way to go.

\section{References}

Alderson, D. and Spencer, R. (eds.). (2017) For Humanism: Explorations in Theory and Politics. London: Pluto Press.

Colebrook, C. (2014) Death of the Posthuman: Essays on Extintion (Vol. 1). London: Open Humanities Press.

Cornell, D. and Seely, S. (2016) The Spirit of Revolution: Beyond the Dead Ends of Man. Cambridge: Polity Press.

Cuboniks, L. (2018) The Xenofeminist Manifesto: A Politics for Alienation. Verso Trade.

Hayles, K. (1999) How we Became Posthuman. Virtual Bodies in Cybernetics, Literature, and Informatics. Chicago: University of Chicago Press.

Jameson, F. (2005) Archaeologies of the Future: the Desire Called Science Fiction and Other Science Fictions. London: Verso.

Noys, B. n.d. "The Poverty of Vitalism (and the Vitalism of Poverty)". Available at https://www. academia.edu/689255/The_Poverty_of_Vitalism_and_the_Vitalism_of_Poverty__Accessed 01 December 2018].

Pilsch, A. (2017). Transhumanism: Evolutionary Futurism and the Human Technologies of Utopia. Minneapolis: University of Minnesota Press.

Williams, A. and Srnicek, N. (2014) \#Accelerate: Manifesto for an Accelerationist Politics. In: R. Mackay and A. Avanessian (eds.) \#Accelerate: The Accelerationist Reader. Falmouth, UK: Urbanomic.

Wolfe, C. (2009) What is Posthumanism. Minneapolis: University of Minnesota Press.

Sara Raimondi

University of Hertfordshire, Hatfield AL10 9EU, UK s.raimondi@herts.ac.uk

Publisher's Note Springer Nature remains neutral with regard to jurisdictional claims in published maps and institutional affiliations.

(C) 2019 Springer Nature Limited. 1470-8914 Contemporary Political Theory Vol. 19, S2, S91-S99 S99 